\title{
Dr. Luis Jiménez Troncoso
}

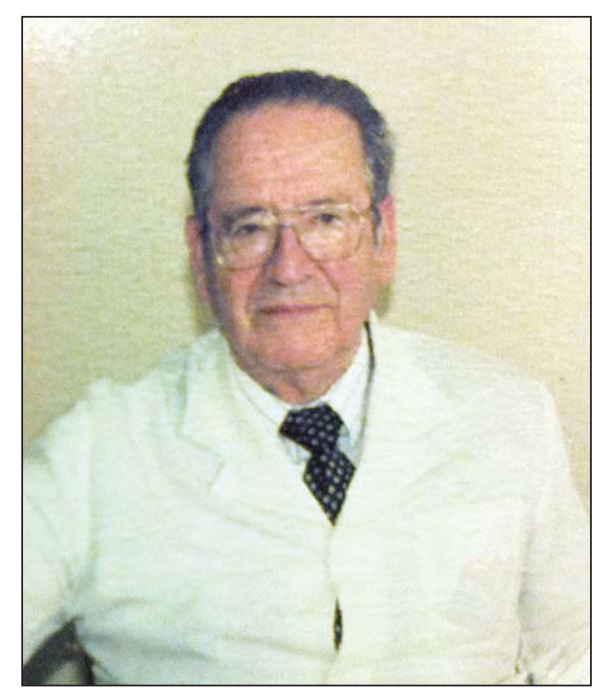

$\mathrm{E}$ 1 Dr. Luis Jiménez Troncoso falleció en Santiago el 25 de septiembre del año 2011, a los 89 años, enfrentando durante largo tiempo una condición invalidante, en su estilo, con entereza y estoicismo. Deja tras de sí una vasta trayectoria de trabajo en Infectología en el Servicio Público de nuestro país.

El Dr. Jiménez nació en Concepción el 21 de junio de 1922. Desarrolló sus estudios universitarios en la Facultad de Medicina de la Universidad de Concepción. Luego de titulado, ejerció en el Hospital Del Salvador, incorporándose al Hospital de Enfermedades Infecciosas Prof. Dr. Lucio Córdova el 1 de abril de 1950. Permaneció en él hasta su retiro, el 1 de junio de 2001. Además se desempeñó por algún tiempo en el Hospital de la Fuerza Aérea de Chile, llegando a ser Subdirector médico y Director subrogante.

A su incorporación al Hospital Lucio Córdova en 1950, el Dr. Roque Kraljevic, en sus "Memorias de un viejo Infectólogo", lo recuerda como el "enfant terrible", alegre, bromista e indisciplinado. El transcurso del tiempo, la experiencia y sus responsabilidades modularon la indisciplina, pero no minaron su esencia, con su entusiasmo, energía y capacidad de liderazgo, que sumados a sus conocimientos y espíritu docente, lo llevaron a asumir el cargo de Jefe de Servicio Clínico y luego Director del Hospital Lucio Córdova.

En sus tres etapas tuve la oportunidad de conocerlo en sus diferentes facetas y apreciar sus cualidades personales y profesionales.

Como médico clínico, destacaba su buen criterio, el conocimiento acabado de la patología infectológica clásica, capacidad docente, generosidad, destreza en procedimientos especiales como las punciones cisternales en pacientes con sospecha de aracnoiditis espinal con bloqueo en el curso de una meningitis tuberculosa.

Como Jefe de Servicio Clínico se le recuerda pasando visitas clínicas con su estilo enérgico, franco, de opiniones certeras, a veces autoritario, pero siempre aportando su conocimiento, experiencia y voluntad en la resolución de los problemas clínicos de los enfermos. En esa época y durante mucho tiempo después se recibían pacientes de otras regiones, aún las más lejanas, para ser estudiados y tratados en el hospital.

Como Director del hospital, fue un defensor de su autonomía y desarrollo, comprometido con su futuro. Durante su gestión se organizó y acreditó la Unidad de Tratamiento Infectológico del hospital, dando respuesta a la creciente complejidad en el manejo de los pacientes con enfermedades infecciosas.

Me correspondió trabajar junto a él como jefe de Servicio Clínico, contando siempre con su apoyo, confianza, reconocimiento y respeto, que agradezco y valoro.

Lamentablemente durante su período de 5 años como Director debió enfrentar problemas de salud progresivos, que supo sobrellevar con valentía y decisión, con la convicción de contar con la lealtad y colaboración de su equipo de trabajo. Quienes formaron parte de él, lo recuerdan con agradecimiento y afecto, por haberles brindado su apoyo y comprensión frente a dificultades.

Paralelamente a su trabajo clínico, participó en trabajos de investigación. Sus temas fueron leptospirosis, brucelosis, tétanos, bacteriemia estreptocóccica y especialmente 
fiebre tifoidea y paratifoidea, su tratamiento y manejo de la portación crónica. Cabe mencionar que en ese período se alcanzaron cifras de atención de hasta 3.000 enfermos con fiebre tifoidea y paratifoidea por año en el Hospital Lucio Córdova, lo que permitió observar casi la totalidad de las complicaciones descritas.

Por otra parte, el Dr. Jiménez participó activamente en la creación de la Sociedad Chilena de Infectología, junto a sus impulsores, Dres. Guillermo Acuña y Marcelo Wolff y al Dr. Mario Salcedo. En asamblea de médicos del 28 de mayo de 1983 se cristalizaría la conformación del primer directorio: Mario Salcedo Sepúlveda (presidente), Patricio Herrera Labarca (vicepresidente), Luis Jiménez Troncoso (secretario), Valeria Prado Jiménez (tesorera), María Eugenia Pinto Claude (directora), Jorge Vergara Calderara (director), Marcelo Wolff Reyes (director) y Guillermo Acuña Leiva (director).

El primer número de Revista Chilena de Infectología apareció en junio de 1984, siendo parte de su Comité Editorial el Dr. Jiménez. Ese mismo año, apenas iniciada las actividades de la Sociedad, se organizó el Primer Congreso.

En 1986, el Dr. Jiménez se desempeñó como secretario ejecutivo del Tercer Congreso de la Sociedad Chilena de Infectología y Primer Encuentro de Infectólogos del Cono Sur. Ese año, recibió un homenaje como director fundador de la Sociedad.

Es cierto, el Dr. Luis Jiménez Troncoso ha partido, pero... los que parten siguen presentes en sus obras y en el afecto de quienes los conocieron y así, hoy no nos resulta difícil recordarlo recitando su poema preferido: "Brindo por la esperanza...”

Nota: mis agradecimientos a Enrique Laval Román por su aporte. También a Laura Bahamondes, Rolando Pizarro, Sra. Leonor Villanueva y Sra. Isabel Matamala, por haber contribuido con sus recuerdos.

Enna Zunino Martini Mayo de 2012 